\begin{tabular}{|l|l|l|l|l|l|}
\hline $\begin{array}{l}\text { Nereis. Revista Iberoamericana } \\
\text { Interdisciplinar de Métodos, } \\
\text { Modelización y Simulación }\end{array}$ & 13 & $99-112$ & $\begin{array}{c}\text { Universidad Católica de } \\
\text { Valencia San Vicente Mártir }\end{array}$ & $\begin{array}{c}\text { Valencia } \\
\text { (España) }\end{array}$ & \begin{tabular}{l} 
ISSN 1888-8550 \\
\hline
\end{tabular}
\end{tabular}

\title{
Role of the PNPase enzyme in the transport of mtRNA in lymphatic cancer: Bibliographic review
}

\author{
Papel de la enzima PNPasa en el transporte de ARNmt en cáncer linfático: Revisión bibliográfica
}

Fecha de recepción y aceptación: 17 de febrero de 2021 y 23 de junio de 2021

DOI: $10.46583 /$ nereis_2021.13.786

\section{Myriam Lizanda Piqueras ${ }^{1 *}$ and Ignacio Ventura González ${ }^{2,3}$}

${ }^{1}$ Departamento de Biotecnología. Facultad de Veterinaria y Ciencias Experimentales. Universidad Católica de Valencia San Vicente Mártir.

${ }^{*}$ Correspondencia: Universidad Católica de Valencia San Vicente Mártir. Facultad de Veterinaria y Ciencias Experimentales. Calle de Guillem de Castro, 94. 46001 Valencia. España.E-mail: mylipi@mail.ucv.es

${ }^{2}$ Departamento de Medicina. Facultad de Medicina y Ciencias de la Salud. Universidad Católica de Valencia San Vicente Mártir

${ }^{3}$ Centro de Investigación Traslacional San Alberto Magno (CITSAM) Universidad Católica de Valencia San Vicente Mártir.

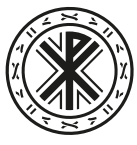

Universidad $\underset{\text { San Vicente Mártir }}{\text { Católica de Valencia }}$

\section{ABSTRACT}

Lymphoma is the most common type of blood cancer today and, as its name suggests, it begins in the lymphatic system. The origin of this disease is related to mitochondrial defects, generated by mutations in the PNPase enzyme or polynucleotide phosphorylase, whose main functions are import and degradation mitochondrial RNA. For this reason, the main objective of the present work was to carry out a bibliographic review of scientific publications that described the important role of this enzyme in relation to mitochondria as the cause of lymphatic cancer.

The methodology used consisted of a bibliometric analysis based on the use of different databases, in which search equations formed from keywords were introduced. Then, the selection of articles related to the study topic and published in the last 20 years was carried out. Subsequently, the journals were analyzed, based on the h-index, in order to determine which supported the hypothesis of the role of PNPase in lymphoma and which stated the opposite.

The results showed that a total of 441,288 scientific publications were obtained, of which 133 were selected to carry out this work. As for the journals, those with the highest h-index were Nature and Cell.

It can be concluded that PNPase plays a very important role in the transport of mitochondrial RNA and that the nuclear transcription factor (NF-Y) is involved in the control of cell growth, therefore, both have a crucial role in the development of this disease. Therefore, research on both PNPase and NF-Y is essential to establish the specific genetic characteristics that define the early lesions of lymphatic cancer and the consequent determination of their treatment.

KEYWORDS: lymphatic cancer, mitochondria, mitochondrial RNA transport, PNPase, PNPT1, NF-Y. 


\section{RESUMEN}

El linfoma es el tipo de cáncer de sangre más común en la actualidad y, como su nombre indica, comienza en el sistema linfático. El origen de esta enfermedad está relacionado con defectos mitocondriales, generados por mutaciones en la enzima PNPasa o polinucleótido fosforilasa, cuyas principales funciones son las de importación y degradación del ARN mitocondrial. Por este motivo, el objetivo principal del presente trabajo fue la realización de una revisión bibliográfica acerca de publicaciones científicas, que hicieran relevancia al papel de esta enzima, en relación con la mitocondria como causante del cáncer linfático.

La metodología empleada consistió en un análisis bibliométrico basado en la utilización de diferentes bases de datos, en las que se introdujeron ecuaciones de búsqueda formadas a partir de palabras clave. Después, se llevó a cabo la selección de los artículos relacionados con el tema de estudio y publicados en los últimos 20 años. Posteriormente, se analizaron las revistas, en función del índice $\mathrm{H}$, para poder observar cuáles apoyaban la hipótesis del papel de PNPasa en linfoma y cuáles decían lo contrario.

Los resultados mostraron que se obtuvo un total de 441.288 publicaciones científicas, de las que fueron seleccionadas 147 para poder llevar a cabo este trabajo. En cuanto a las revistas, las que presentaron un índice H mayor fueron Natura y Cell.

Se puede concluir que la PNPasa desempeña un papel muy importante en el transporte del ARN mitocondrial, y que el factor NF-Y está involucrado en el control del crecimiento de las células, por lo que, ambos presentan una función crucial en el desarrollo de esta enfermedad. Por ello, la investigación, tanto de PNPasa como de NF- Y, es fundamental para establecer las características genéticas concretas, que definan las lesiones tempranas del cáncer linfático y la consiguiente determinación de su tratamiento.

PALABRAS CLAVE: cáncer linfático, mitocondria, transporte de ARN mitocondrial, PNPasa, PNPT1, NF-Y.

\section{INTRODUCTION}

Lymphoma is the type of cancer that begins in the lymphatic system, which is made up of an extensive network of vessels and nodes $[1,2]$. Lymphoma presents an extensive nature, so it allows the rapid spread of cancer cells, a process known as metastasis [1, 3]. For this reason, lymphatic cancer is a malignant proliferation of lymphocytes that occurs within the nodes, and which can affect other tissues, such as the spleen or the liver, and is a neoplastic disease [4]. According to the classification, there are two types of lymphatic cancer: Hodgkin and Non-Hodgkin, which are differentiated by the presence of abnormal cells, known as "Reed-Sternberg cells", which are damaged B lymphocytes. Hodgkin lymphoma is less harmful [5-7].

The origin of this disease may be related to the mitochondria. Two metabolic pathways, oxidative phosphorylation and glycolysis occur in them, which are essential to supply the energy required for cell proliferation $[8,9]$. In the case of normal mitochondria, both routes are in balance, while cancer cells have faulty cellular respiration, causing these cells to use glycolysis followed by lactic fermentation to get energy [10-12]. This alteration is called the Warburg effect and its origin is due to mitochondrial defects that inhibit effective oxidation capacity $[13,14]$. Therefore, dysfunctional mitochondria indirectly cause this disease of cancer. 
This problem is related to the mechanism of import of RNA into the mitochondria, which is efficiently carried out by the enzyme polynucleotide phosphorylase or also known as PNPase. The protein is located in the intermembrane space (IMS), although it has also been detected in the mitochondrial matrix [15-17]. Under normal conditions, it is located in the IMS, where it facilitates the translocation of mitochondrial RNAs (mtRNAs). Once inside the mitochondrial matrix, this enzyme breaks down mtRNA, playing an important role in the maintenance of mitochondrial DNA [18].

Structural studies of PNPase propose a mechanism by which this enzyme selects RNAs, recognizing stem-loop structures, for their mitochondrial import [19]. For this, it should be noted that it consists of two RNase PH domains, an $\alpha$ helical domain, and two RNA binding domains, $\mathrm{KH}$ and S1, which are the most important [18]. The mechanism carried out by this protein consists of the use of the KH domains for binding to single-stranded RNA, and the S1 domains for double-stranded RNA, since both are able to form a pore, allowing the passage of RNA into the enzyme and its interaction with the catalytic site. When the length of the 3'-end of the RNA is very short, the S1 domains prevent its entry into the $\mathrm{KH}$ pore and therefore into the $\mathrm{PH}$ channel, protecting it from degradation $[16,20]$.

This enzyme is encoded by the old-35 gene, also known as PNPT1 (polyribonucleotide nucleotidyltransferase 1), and, for this reason, it participates in the processing of mtRNA. Therefore, the mutations in PNPT1 reduce the activity of PNPase since the enzyme changes its conformation from trimeric to dimeric proteins. These proteins show impaired activities of degradation and binding of RNA, so that its import is reduced, generating mitochondrial dysfunction, leading to genetic disorders and diseases [18] such as lymphatic cancer [21,22].

In addition, the presence of a transcription factor, known as NF-Y stands out for being an important regulatory element due to its role in gene regulation of the Major Histocompatibility Complex (MHC), which is crucial in the immune response [23]. Information is limited, but it has been found that it plays a very important regulatory role in the expression of genes involved in apoptosis, cell cycle progression and proliferation, thanks to the fact that it is able to bind and regulate its transcription. So it is involved in the control of cell growth, which is critical for preventing cancer since uncontrolled proliferation is the main characteristic of cancer cells [24-26]. In this way, it is confirmed that PNPase and the transcription factor NF-Y play a fundamental role in the development of lymphatic cancer.

The general objective of this study was to carry out a bibliographic review of all the scientific publications that refer to the role of PNPase in relation to mitochondria, as the cause of lymphatic cancer. Thus, the objectives of the work have been, on the one hand, to discover the role of the PNPase enzyme in relation to the transport of mitochondrial RNA in lymphatic cancer and, on the other hand, to identify the most frequent RNAs transported by PNPase in lymphoma. We also explored the relationship of NF-Y to the appearance of lymphatic cancer, and, finally, proposed future lines of research that should be carried out in order to increase knowledge and advance diagnosis and treatment of lymphoma. 


\section{MATERIAL AND METHODS}

The methodology used to carry out this review was the classical documentary analysis method, in order to obtain the "state of the art" on the subject of study, as well as the detection and analysis of the various sources of information.

In this case, a bibliographic search was performed on the role of the PNPase enzyme in relation to the transport of mtRNA, in order to identify the most frequent RNAs transported by the enzyme in lymphoma.

\section{Bibliographic search}

In order to carry out the bibliographic search, a period of time was defined that included from January 2000 to May 2020. The search was carried out mainly in English, as it is the vehicular language in the biotechnological field, as well as in Spanish. The keywords used for this study were: lymphoma, mitochondria, PNPase, PNPT1, mtRNA transport and NF-Y. The databases consulted were Google Scholar, ScienceDirect, Web Of Science (WOS), PubMed (NCBI), Medline and Dialnet.

\section{Selection criteria}

Articles that met the following requirements were included in this review:

- Articles that support the hypothesis that PNPase has an important role in lymphoma.

- Published in books, Web portals, scientific journals, bibliographic reviews and works, in which a previous selection of the information was made.

- Articles whose titles are related to the scope of study of this work, as well as its objectives, must be in accordance with the information intended to be presented.

- Published in both Spanish and English and between the years 2000 and 2020.

Articles that met the following requirements were excluded from this study:

- Published on web pages or magazines that lack relevant scientific information, as well as without constant reviews and updates.

- Studies whose titles and objectives have no relation to this work.

- Publications in a language other than English and that are outside the 2000-2020 chronological range.

\section{Search equations}

The way in which the selection of documents was carried out for this work, used keywords related to the study topic, which were connected by boolean operators such as "AND" is used to obtain 
documents that contain all the terms, "OR" used to find information that contains at least one of the terms, and "NOT" is used so that the specific concept is not included in the documents. The results obtained exclude one of the terms, so information is sought that have the first term but not the second.

The first thing that was done was to perform a general search (Table 1), in order to obtain a globalized view of the information and thus, be able to adequately define the search equation related to the purpose of the study. Once the overview was acquired, we proceeded to propose specific search equations (SSE), in order to obtain more specific and centralized information (Table 1).

Table 1. General and specific search equations entered in the different databases.

Searches carried out between January and April 2020

\begin{tabular}{cc}
\hline Search equation & Name and abbreviation \\
\hline $\begin{array}{c}\text { (Lymphoma* OR lymphatic cancer*) AND } \\
\text { (Mitochondria* OR IMS* OR mitochondrial } \\
\text { matrix*) AND (Warburg Effect*) }\end{array}$ & General search equation 1 (GSE-1) \\
(Lymphoma* OR lymphatic cancer*) AND (Lymphatic & \\
system* OR nodes* OR lymphocytes*) AND & \\
(PNPase* OR Polyribonucleotide phosphorylase*) & General search equation 2 (GSE-2) \\
(Lymphoma* OR lymphatic cancer*) AND & \\
(Mitochondria* OR IMS* OR mitochondrial matrix*) & \\
AND (Hodgkin* OR Reed-Sternberg cells*) & Specific search equation 1 (SSE-1) \\
(Mitochondria* OR IMS* OR mitochondrial matrix*) & \\
AND (Import* OR transport*) AND (Mitochondrial & \\
RNA* OR ARNt* OR ARNr 5S* OR ARN H1* OR & \\
RMRP* OR SAMMSON* OR hTERC* OR miARN*) & \\
AND (PNPase* OR Polyribonucleotide phosphorylase*) & \\
(PNPase* OR Polyribonucleotide phosphorylase*) & \\
AND (PNPT1* OR gene encodes PNPase*) AND & \\
(Type I interferon* OR IFN 1* OR IFN $\beta^{*}$ ) AND & \\
(Mutation* OR amplification* OR deletion*) & \\
(NF-Y* OR nuclear factor Y* OR CBF* OR & \\
binding factor to CMP*) AND (CCAAT box*) & \\
AND (Subunit* OR NF-YA* OR NF-YB* OR NF- & \\
YC*) AND (HFD* OR histone folding domain*) & \\
\hline
\end{tabular}

Once the search was completed, the articles found and selected in each database were classified to analyze the number of publications obtained in each of them and see which had the highest number of results.

Finally, an analysis was carried out of the journals based on their h-index. This is a system for measuring quality, based on the number of citations that the scientific articles published in them have; and the quartile, which allows knowing the importance of a journal within an area, which, in this case, corresponds to that of scientific research. 


\section{RESULTS AND DISCUSSION}

The results of the bibliometric analysis are shown in Table 2, showing the number of documents obtained after using the search equations, previously described, in the different databases.

Table 2. Number of documents obtained and used when entering search equations into databases

\begin{tabular}{ccc}
\hline Databases & Articles found & Articles used \\
\hline Web Of Science & 363,507 & 29 \\
Science Direct & 47,195 & 27 \\
Google Scholar & 30,181 & 37 \\
PubMed & 331 & 23 \\
Medline & 60 & 7 \\
Dialnet & 17 & 147 \\
\hline TOTAL & 441,291 & 74 \\
\hline
\end{tabular}

After using 6 databases, 2 general search equations and 4 specific equations, a total of 441,291 scientific publications were found, of which 147 were selected to carry out this work. However, some of the documents were repeated, regarding the databases and the searches carried out.

In order to carry out a more detailed analysis, a Pie Chart was made (Figure 1), where the different databases used were represented based on the number of publications obtained in each one. The one that provided the highest number of results was Web Of Science because it is the most important citations database in the world, thanks to the fact that it provides a multidisciplinary vision. However, the smallest number of results was obtained from Dialnet, since it focuses more on Hispanic articles, related to studies carried out in Spain. 


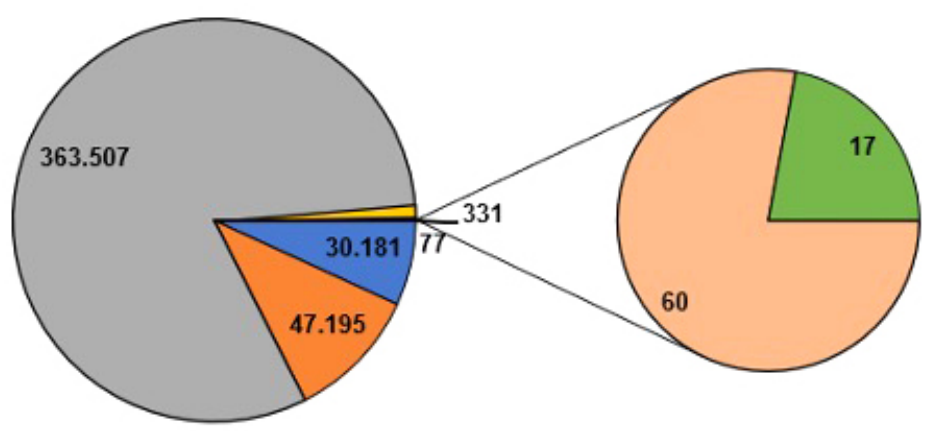

$\square$ Google Scholar $\square$ ScienceDirect $\square$ Web Of Science $\square$ PubMed $\square$ Medline $\square$ Dialnet

Fig. 1. Pie Chart showing the databases used with the results obtained in each one, after the use of the search equations. Source: own elaboration.

Finally, Figure 2 shows a bar graph representing the journals, in which the different articles were published, based on their h-index. The majority of the journals were in the first quartile, except Journal of Bioenergetics and Biomembranes and Progress in Molecular Biology and Translational Science, which belong to Q2; Case Reports in Oncological Medicine, which is from Q3; Hematology, American Journal of Medical Genetics and Cells, which have no identified quartile.

Also Figure 2 shows that Nature, Cell and Proceedings of the National Academy of Sciences of the United States of America are the journals that are in the first quartile and present the highest h-index, and also, which means that their quality, based on citations, and importance, within the area of scientific research, are high, thus supporting the hypothesis of the crucial role of PNPase in lymphatic cancer. On the contrary, those that have a lower h-index and are not even found within any quartile, are those that do not support this theory. 


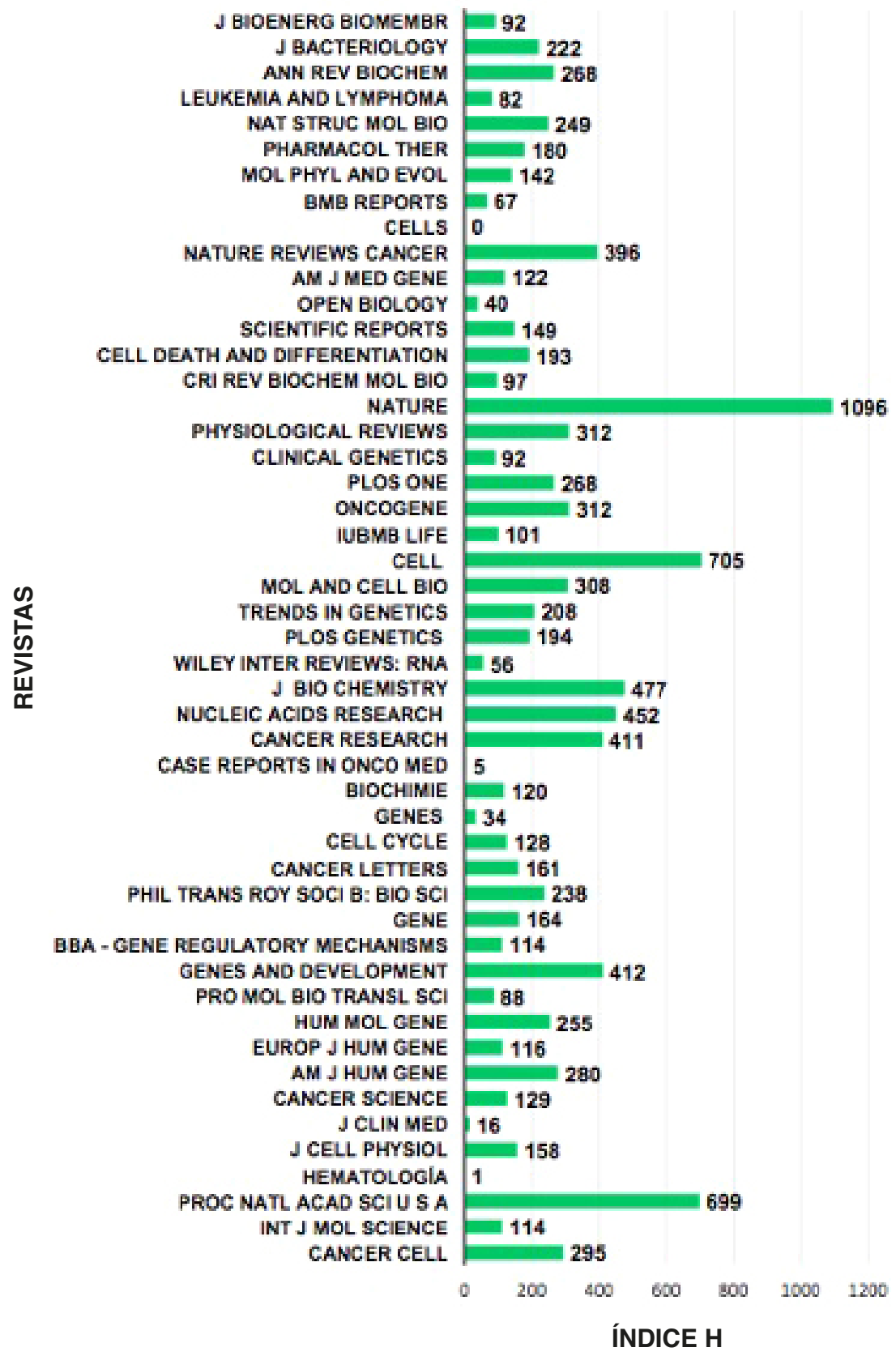

Fig. 2. Bar graph representing the journals used according to their h-index. Source: own elaboration.

In this way, it was possible to deduce which were the most relevant articles for the present work, since they covered the role of PNPase in the import of mitochondrial RNA, the PNPT1 gene that encodes this enzyme, the identification of the types of mtRNA and the function of NF-Y in the control of cell growth. 
The first article selected was that of the study by Jeandard et al., 2019, with the title Import of non-coding RNAs into human mitochondria: A critical review and emerging approaches. The results and conclusions that they obtained were: "The nuclear transcripts detected in mitochondria are very diverse in terms of structure, function and size, but they are all non-coding RNA, that is, the nucleus does not supply mRNA to the mitochondria's genetic system, so all translated polypeptides in ribosomes they are of mitochondrial origin. This characteristic is common to all, so the RNA import route is limited to a group of non-coding species and, generally, of small size, such as tRNA, 5S rRNA, H1 RNA, RMRP, SAMMSON, hTERC and miRNAs. For the importation of said mtRNA to be carried out efficiently, it has to be carried out by the PNPase enzyme, which previously selects the RNAs, recognizing their stem-loop structures, through the $\mathrm{KH}$ and S1 domains, which are for binding to single-stranded and double-stranded RNA, respectively".

This is a review of the types of RNA imported into mitochondria in humans and the molecular mechanisms of targeted RNA, highlighting the role of polynucleotide phosphorylase (PNPase) to carry out this transport. In addition, classical and new methods were also studied to carry out research on the mitochondrial location of RNA and to be able to characterize, in a complete way, the mitochondrial RNA complex.

The second article was that of Rius et al., 2019, with the title Clinical Spectrum and Functional Consequences Associated with Bi-Allelic Pathogenic PNPT1 Variants. The results and conclusions of this study were: "A study was carried out on patients with biallelic pathogenic variants of the PNPT1 gene. This research resulted in a great phenotypic heterogeneity associated with these variants, in which the most common neurodevelopmental abnormalities were developmental delay and severe regression, optic atrophy, hearing loss, etc. Images of the brain of the 17 patients were taken, in which it was observed that 8 of them had abnormalities in the white matter, others a thin corpus callosum $(\mathrm{n}=5)$ and the last 4 showed abnormalities in the basal ganglia. But, after performing spectrophotometric tests, all of them had irregularities in oxidative phosphorylation, which shows that the diagnosis of disease is related to PNPT1".

This was based on the PNPT1 gene, which codes for the polynucleotide phosphorylase enzyme, thus participating in multiple mitochondrial RNA processing functions. In this study, they placed special emphasis on their biallelic pathogenic variants, which cause heterogeneous clinical phenotypes, affecting various organs, without correlation between genotype and phenotype, highlighting that mutations in PNPase can generate defects in the mitochondrial respiratory chain. To demonstrate this, they conducted a study of clinical and molecular phenotypes of patients with biallelic variants of this gene, verifying that the variants generated defects in RNA processing, causing irregularities in oxidative phosphorylation enzymatic activities (OXPHOS). In this way, this research expanded the knowledge of the functional and clinical consequences of the PNPT1 variants, guiding the pathophysiological mechanisms for therapeutic development.

The third article selected was that of Cameron, Matz \& De Lay, 2018, with the title Polynucleotide phosphorylase: Not merely an RNase but a pivotal post-transcriptional regulator. In this article, the results and conclusions were: "PNPase is a fundamental enzyme in the metabolism of RNA in eukaryotes and bacteria, where it stands out for its participation in the processing and degradation of these. As each of the RNAs can regulate various transcripts, PNPase affects most of the regulatory circuits in cells, so that most of the phenotypes associated with decreased activity are due to its role in the 
stability of RNAs. On the other hand, this enzyme is responsible for the importation of RNA into the mitochondrial matrix, where it degrades polyadenylated non-coding RNAs and messengers, when release occurs in the cytoplasm, after permeabilization of the mitochondrial membrane in the apoptosis process. playing a very important role in the maintenance of mitochondrial DNA. Therefore, PNPase is vital for the proper functioning of mitochondria and for the life of organisms".

This is a review that deals with the study carried out by Severo Ochoa 60 years ago, which discovered the enzymatic synthesis of RNA carried out by polynucleotide phosphorylase (PNPase). They explain the role of this enzyme in mammals, which is essential in mitochondria, and therefore, the inactivation of the gene that encodes it, reduces its activity, generating serious consequences, such as impaired growth, loss of virulence and decreased responses to stressful situations, triggering genetic disorders and diseases such as hereditary hearing loss, late myelination, Leigh's syndrome, encephalomyopathy and severe axonal neuropathy.

The fourth article selected was the study by Belluti et al., 2018, with the title An autoregulatory loop controls the expression of the transcription factor $N F-Y$.

The results and conclusions were: "It was a study to know the relationship between the role of the transcription factor NF-Y and the appearance of various pathologies. In the first place, in vivo deactivation of NF-YA was performed in mouse postmitotic neurons, eliminating exons 3-8 of the total 9 encoders, which resulted in a significant increase in NF-YA mRNA and NF-YC. On the other hand, the same study was carried out, but in mice with Huntington's disease, which were characterized by the localization of NF-YA and NF-YC in nuclear inclusions, where the same results were finally obtained as in the previous experiment. These results suggest that there is a negative feedback, which acts as a compensatory system, allowing the adjustment of the NF-Y activity and therefore, counteracting its functional deterioration. In addition, it was observed that the overexpression of NF-Y subunits gives rise to cancer cells, therefore, they focused on studying the reason for the increase in expression, which could be due to the transcriptional regulators of the NF- genes. They are abnormally expressed in cancer cells and therefore alter expression; or due to the self-regulatory mechanism of NF-Y."

This was based on the CCAAT box-binding transcription factor NF-Y. In this study, they highlighted the presence of subunits (NF-YA, NF-YB, NF-YC), whose overexpression or absence is related to the appearance of cancer. With this work, it was found that NF-Y plays a crucial role in physiological and pathological processes, providing great knowledge about cell transformation and cancer-related processes, which occurs when the activity of this factor is altered.

The fifth and last article was that of Liu et al., 2018, with the title PNPT1 release from mitochondria during apoptosis triggers decay of poly (A) RNAs. The results and conclusions of this study were: "They focused on studying the RNA sequence of apoptotic cells, which showed that both mRNAs and poly (A) decomposed, a process that began at the 3 'end. In addition, they discovered that the enzyme encoded by the PNPT1 gene was released from the IMS (mitochondrial intermembrane space) with cytochrome $\mathrm{c}$ during MOMP, thus triggering the decomposition of RNAs, confirming the role of this gene in the degradation process. Subsequently, they tested with the elimination of PNPT1, which significantly inhibited cell death in 2 experiments, confirming the importance of RNA decomposition in the apoptosis process". 
This was based on the study of the PNPT1 gene, in relation to the decomposition of RNAs in the intermembrane space of the mitochondria, which is a process that depends on the permeabilization of the mitochondrial outer membrane (MOMP) and of the control enzymes. Therefore, the main objective of this study was to understand how MOMP causes the decomposition of RNAs and which ones are degraded. However, they also studied the apoptotic disintegration effect of RNA, which is not limited to cancer cells or cells that divide uncontrollably.

\section{CONCLUSIONS}

1. PNPase carries out the import and degradation of mitochondrial RNA effectively, therefore, mutations in this enzyme change its conformation from a trimeric to a dimeric protein, which shows impaired RNA binding and degradation activities, which also impairs import, generating dysfunctional mitochondria.

2. The most frequent RNAs imported into the mitochondria by PNPase in lymphoma are tRNA, 5S rRNA, H1 RNA, RMRP, SAMMSON, hTERC and microRNAs.

3. The factor NF-Y plays a very important role in the regulation of transcription of genes involved in apoptosis, cell cycle progression and proliferation, that is, it is involved in the control of cell growth, which is crucial to prevent cancer, since uncontrolled proliferation is the main characteristic of cancer cells.

4. PNPase research should focus on linking its location with the functions it performs, thus understanding the effects it causes on energy metabolism, senescence, RNA processing, antiviral responses and tumorigenesis, to establish genetic specific characteristics that define the early lesions of the cancer, and the consequent determination of its treatment.

\section{FUTURE LINES OF RESEARCH}

During the development of this bibliographic study, because the knowledge about the PNPase enzyme functioning is limited, the following lines of research are proposed:

- To clarify which signalling pathways, if any, lead to the activity of this enzyme in the cytosol.

- To develop new, more sensitive techniques that determine the existence of traces of endogenous PNPase in the mitochondrial matrix or in the cytosol.

- To describe the process by which PNPase causes substrate specificity, and thus understand its RNA processing functions more clearly.

- To discover the mechanism by which this enzyme maintains oxidative phosphorylation, which is a challenging but crucial area for cancer research.

- To highlight the important role that PNPase performs in mitochondrial homeostasis, because it is unknown, whether it is carried out through a mode of action independent of its exoribonuclease and RNA polymerase activities. 
- To study in depth the main emerging research areas in which polynucleotide phosphorylase participates, which are two: antiviral responses and tumorigenesis, both of particular biomedical importance.

- To enhance the link between PNPase and cancer after the identification of TCL1 oncoprotein, a non-enzymatic adapter molecule that increases the signalling pathways AKT (protein kinase B) and mitogen-activated protein kinase $\mathrm{C}$ (PKC-MAPK), to improve cell survival and proliferation, since the tumorigenic mechanism remains resolved, but incompletely.

- Linking location to function in the mitochondrial matrix or within the cytosol will be crucial for understanding how PNPase mediates effects on energy metabolism, RNA processing, senescence, and potentially antiviral responses and tumorigenesis. So, to be able to establish the exact gene characteristics that define the early lesions of lymphoma, the evaluation of the risk of clinical progression and the determination of their treatment.

\section{ACKNOWLEDGEMENT}

This work was carried out at the Catholic University of Valencia. Thank you for the help provided by the services of the university and to the teaching staff for the support provided during the completion of the work.

\section{LITERATURE CITED}

[1] Vander AJ, James H, Sherman DS, Luciano. Human Physiology, 6th Edition. McGraw-Hill, Inc. NY. 1994.

[2] Connect E. Anatomía del sistema linfático: componentes y funciones. 2019.

[3] Fleisher TA, Shearer WT, Schroeder HW, Frew AJ, Weyand CM, Rich RR. Inmunología clínica. Principios y práctica. Quinta edición. Elsevier. 2019.

[4] Pérez-Zúñiga JM, Aguilar-Andrade C, Álvarez-Vera JL, Augusto-Pacheco M, Báez-Islas PE, Bates-Martín RA, et al. (2018). Generalidades sobre linfomas. Revista de Hematología. 2018;19:174-188.

[5] Walter J. La guía sobre el linfoma. Información para pacientes y cuidadores. Leukemia \& Lymphoma Society. 2014.

[6] Albarrán B, Caballero D, Cabezudo M, Cabo E, Cidoncha B, Fernández S, et al. Guía de linfomas. ISBN: 978-84-940139-6-6. DL: M-22628-2017. Doing Soluciones Graficas S.A. 2017.

[7] Antón Rodríguez Á y Desvaux García M. Factores pronósticos en el linfoma de Hodgkin. Revisión de una serie clínica. 2019.

[8] Cuezva JM, Ortega AD, Willers I, Sanchez-Cenizo L, Aldea M, SanchezArago M. The tumor suppressor function of mitochondria: translation into the clinics. Biochim Biophys Acta. 2009; 1792:1145-1158.

[9] Formentini L, Martinez-Reyes I, Cuezva JM. The mitochondrial bioenergetic capacity of carcinomas. IUBMB Life. 2010;62:554-560. 
[10] Galluzzi L, Kepp O, Heiden MGV, Kromer G. Metabolic targets for cancer therapy. Nat Rev Drug Discov. 2013;12:829-46.

[11] Valle A y Soto I. Metabolismo energético y cáncer. Vertientes Rev Esp en Ciencias de la Salud. 2014;17:108- 13.

[12] Freyre-Bernal SI, Saavedra-Torres JS, Zúñiga-Cerón LF, Salguero C. Cáncer y mitocondria: un aspecto central. 2017.

[13] Warburg O, Posener K, Negelein E. Uber den Stoffwechsel der Tumoren. Biochemische Zeitschrift. 1924;152:319-44.

[14] Mendiola AV y Soto Cruz I. Metabolismo energético y cáncer. Vertientes Revista Especializada en Ciencias de la Salud. 2014;17:108-113.

[15] Wang G, Shimada E, Koehler CM, Teitell MA. PNPASE and RNA trafficking into mitochondria. Biochimica et Biophysica Acta (BBA)-Gene Regulatory Mechanisms. 2012;1819:998-1007.

[16] Golzarroshan B, Lin CL, Yang WZ, Chu LY, Agrawal S, Yuan, H. S. Crystal structure of dimeric human PNPase reveals why disease-linked mutants suffer from low RNA import and degradation activities. Nucleic acids research. 2018;46:8630-8640.

[17] Jeandard D, Smirnova A, Tarassov I, Barrey E, Smirnov A \& Entelis N. Import of non-coding RNAs into human mitochondria: A critical review and emerging approaches. Cells. 2019;8:286.

[18] Cameron TA, Matz LM, De Lay NR. Polynucleotide phosphorylase: Not merely an RNase but a pivotal post-transcriptional regulator. PLoS genetics. 2018;14.

[19] Lin CL, Wang YT, Yang WZ, Hsiao YY, Yuan HS. Crystal structure of human polynucleotide phosphorylase: insights into its domain function in RNA binding and degradation. Nucleic Acids Res. 2012;40:4146-4157.

[20] Wang G, Chen HW, Oktay Y, Zhang J, Allen EL, Smith GM, et al. PNPASE regulates RNA import into mitochondria. Mol. Cell. 2010;142:456-467.

[21] Fukuhara N, Tagawa H, Kameoka Y, Kasugai Y, Karnan S, Kameoka J, et al. Characterization of target genes at the 2p15-16 amplicon in diffuse large B-cell lymphoma. Cancer Science. 2006;97:499-504.

[22] Yu YL, Chou RH, Wu CH, Wang YN, Chang WJ, Tseng YJ, et al. Nuclear EGFR suppresses ribonuclease activity of polynucleotide phosphorylase through DNAPK-mediated phosphorylation at serine 776. Journal of Biological Chemistry. 2012;287:31015-31026.

[23] Sachini N \& Papamatheakis J. NF-Y and the immune response: dissecting the complex regulation of MHC genes. Biochimica et Biophysica Acta (BBA)-Gene Regulatory Mechanisms. 2017; 1860:537-542.

[24] Van der Watt PJ \& Leaner VD. The nuclear exporter, Crm1, is regulated by NFY and Sp1 in cancer cells and repressed by p53 in response to DNA damage. Biochim. Biophys. Acta BBA Gene Regul. Mech. 2011;1809:316-326.

[25] Imbriano C, Gnesutta N \& Mantovani R. The NF-Y/p53 liaison: Well beyond repression. Biochim. Biophys. Acta BBA Rev. Cancer. 2012;1825:131-139.

[26] Dolfini D, Andrioletti V \& Mantovani R. Overexpression and alternative splicing of NF-YA in breast cancer. Scientific reports. 2019;9:1-12. 
[27] Rius R, Van Bergen NJ, Compton AG, Riley LG, Kava MP, Balasubramaniam S, et al. Clinical Spectrum and Functional Consequences Associated with Bi-Allelic Pathogenic PNPT1 Variants. Journal of clinical medicine. 2019;8.

[28] Belluti S, Semeghini V, Basile V, Rigillo G, Salsi V, Genovese F, et al. An autoregulatory loop controls the expression of the transcription factor NF-Y. Biochimica et Biophysica Acta (BBA)Gene Regulatory Mechanisms. 2018;1861:509-518.

[29] Liu X, Fu R, Pan Y, Meza-Sosa KF, Zhang Z, Lieberman J. PNPT1 release from mitochondria during apoptosis triggers decay of poly(A) RNAs. Cell. 2018;174:187-201.e112. 